\title{
Assessment of the pure sowing of different legumes and in mixtures with grass on productivity and damage level by Sitona spp. and Otiorrhynchus ligustici (LINNAEUS, 1758) (Coleoptera: Curculionidae)
}

\author{
IVElina MitKova NikOlova*, NATAliYa Anastasova GeORGIEVA, \\ VILIANA MARINOVA VALISEVA
}

Institute of Forage Crops, Department of Technology and Ecology Forage Crops, 89 Gen. Vl. Vazov St., 5800 Pleven, Bulgaria

\begin{abstract}
This work examined the impact on productivity of the cultivation system of perennial legumes such as sainfoin (Onobrychis viciifolia), bird's-foot trefoil (Lotus corniculatus) and alfalfa (Medicago sativa), grown pure and in binary mixtures with cocksfoot and on damage caused by root pests of Sitona spp. and Otiorrhynchus ligustici. It was found that the productivities of aboveground and root biomasses in binary mixtures were significantly higher compared to the corresponding legume monocultures on average by 30.7 and $39.7 \%$ respectively in mixtures with sainfoin, by 15.0 and $73.1 \%$ in mixtures with bird's-foot trefoil, and by 18.7 and $49.6 \%$ in mixtures with alfalfa. The weight of dry aboveground biomass in the pure leguminous crops slightly exceeded that of the corresponding leguminous components in the mixtures, whereas the productivity of cereal plants in mixed crops was significantly lower compared to the pure cocksfoot on average by $38.5,47.0$ and $51.7 \%$ in mixtures of sainfoin, bird's-foot trefoil and alfalfa respectively. A similar tendency was observed with regard to dry root biomass. Damage to nodules by Sitona larvae in mixtures decreased significantly: on average by $33.5 \%$ (sainfoin + cocksfoot), by $50.3 \%$ (bird's-foot trefoil + cocksfoot) and by $55.6 \%$ (alfalfa + cocksfoot) compared to pure grown legumes. The damage caused by Otiorrhynchus ligustici, as expressed by the length of gnawed furrows, in the mixtures with sainfoin, bird's-foot trefoil and alfalfa decreased considerably - by $12.5,77.8$ and $59.5 \%$, respectively - compared to the pure crops. The damage caused by the alfalfa snout beetle had the most significant negative effect on aboveground and root biomass productivities. Mixed cultivation systems of forage crops are an economically and ecologically sustainable method of insect pest control.
\end{abstract}

KEY WORDS: forage, productivity, Sitona spp., Otiorrhynchus ligustici.

\footnotetext{
* Corresponding author: imnikolova@abv.bg
} 


\section{INTRODUCTION}

Mixed cultivation systems of forage crops are based on ecological principles and can be more stable and productive than monoculture systems. In mixed communities, there is greater species diversity, complementarity between plant species in terms of available resources, symbiosis interactions (PICASSO et al. 2011), for example, which creates necessary prerequisites for high productivity and environmental stability.

There are a number of studies that have investigated the composition of appropriate legume and grass components in forage mixtures for intensive pasture use, as well as for ensuring a more even distribution of dry matter, superior forage quality and greater stability during the pasture season (GERRISH 2001, TRACY \& SANDERSON 2004, THARMARAJ et al. 2007, SANDERSON 2010, WOODWARD et al. 2013).

There are relatively fewer studies in mixed associations related to the impact of stress factors such as drought, pests, weeds and diseases, which pose a significant risk and reduce forage productivity. A number of environmental studies have shown that a greater variety of species in grassland ecosystems increases and stabilizes productivity in stressful conditions (TILMAN 1999, MINNS et al. 2001). Intercropping is an important cultural practice for pest control. This is based on reducing insect density by increasing ecosystem diversity (SMITH \& MCSORLEY 2000, RISCH 2005, MOONEN \& BÀRBERI 2008); in mixed crops, a pest finds fewer acceptable hosts to feed or lay eggs on compared to monoculture crops.

Mixed cultivation of legumes and grasses reduces the number of pests and the damage they cause, improves control through so-called "bottom-up" and "top-down" control mechanisms (TILlman et al. 2004, SASTAWA et al. 2004, TOOKER \& FrANK 2012) and reduces the invasion of weed species (FARGIONE et al. 2003, ZAVALETA \& HULVEY 2004) compared to pure crops, thus creating conditions for a stable and functional ecosystem. SKINNER et al. (2006) reported that the growth of plant species diversity in mixed crops may increase forage yield, resistance to weed invasion and carbon sequestration in the soil by including high-yielding forage species. However, the density of a mono- or oligophagous insect pest may not be reduced by a mixed cultivation system (ANDOW 1991). In contrast, polyphagous species that are characterized by a wide range of hosts often adapt better but are present at a lower density in mixed systems (HUREJ \& TWARDOWSKI 2003).

Insect pests that have a root-feeding larval stage as one of the stress factors can, under favourable conditions, significantly disturb the stability of an ecosystem. They often cause the most sustained damage to plants because their attrition remains largely unseen, preventing early diagnosis and treatment. The use of a mixed system of cultivation of forage crops is related to its considerable impact on insect pest density and leads to increased activity of predators and pest vulnerability (STRAUB et al. 2013). FENG et al. 
(2011) reported that mixed cultivation of alfalfa in tea plantations led to a $77 \%$ reduction in harmful species, a 10-17\% increase in the number of useful insects and the absence of damage leading to forage yield reduction.

The purpose of this study was to determine the effect of a cultivation system of perennial legumes (sainfoin, bird's-foot trefoil and alfalfa), grown pure and in mixtures with cocksfoot, on productivity and the level of damage caused by the root pests Sitona spp. and Otiorrhynchus ligustici (LINNAEUS, 1758).

\section{MATERIAL AND METHODS}

The trial was performed in the experimental field of the Institute of Forage Crops, Pleven, Bulgaria, from 2014 to 2017. Sainfoin (Onobrychis viciifolia SCOP.), bird's-foot trefoil (Lotus corniculatus L.) and alfalfa (Medicago sativa L.) were sown alone (100\%) and in mixtures with cocksfoot (Dactylis glomerata GRAEBN.) (50:50\%) (Table 1). Perpendicular to the main crops and mixtures in the first year (2014), spring forage pea was sown as a cover crop with a $75 \%$ sowing rate. The experimental plot size was $10 \mathrm{~m}^{2}$ with four replications according to a methodology of field experience (SHANIN 1977). Four samples of each type of crop and mixture were analysed, i.e. a total of 24 samples in each year.

Table 1. Variants of the experiment.

\begin{tabular}{lcc}
\hline \multicolumn{1}{c}{ Variants } & Ratio, \% & Sowing rate, kg/ha \\
\hline Sainfoin (Onobrychis viciifolia SCOP.) (local population) & 100 & 120.0 \\
Bird's-foot trefoil (Lotus corniculatus L.) cv. Leo & 100 & 15.0 \\
Alfalfa (Medicago sativa L.) cv. Pleven 6 & 100 & 25.0 \\
Sainfoin + cocksfoot (Dactylis glomerata GRAEBN.) & $50: 50$ & $60.0+17.5$ \\
Bird's-foot trefoil + cocksfoot & $50: 50$ & $7.5+17.5$ \\
Alfalfa + cocksfoot & $50: 50$ & $17.5+17.5$
\end{tabular}

The genus Sitona GERMAR, 1817 comprises about 100 species (VELASQUEZ DE CASTRO et al. 2007). All of them feed on Fabaceae in both larval and imaginal stages. The larva of Sitona species feed on root nodules, and feeding damage caused by adult beetles is revealed as notches on the leaf margins.

Otiorrhynchus ligustici imagos damage leaves, buds and the upper parts of plants. Such damage is of no economic importance. The main damage of these weevils is caused by their 
larvae, which gnaw deep longitudinal furrows on alfalfa roots, thus imparing the plant's growth and development.

To investigate the larval damage of these pests to the root system of the plants in the flowering stage - the beginning of pod formation of legume crops in the second regrowth soil monoliths 20 (width) x 50 (length) x 40 (height) cm were taken in the period 20152017. After rinsing with water, the plants were carefully separated to preserve their integrity and nodule biomass. The following characteristics were recorded: percentage of nodules damaged by Sitona weevil larvae calculated as the ratio of the number of damaged nodules $\times 100$ to the total number of nodules; the degree of damage caused by Otiorrhynchus ligustici larvae as measured by the length of spiral furrows on the plant roots $(\mathrm{cm})$; the productivity of dry aboveground biomass; dry root biomass (g/plant). The data of the productivity of dry aboveground and root biomass were processed statistically using ANOVA for a one-factor case, the mean being compared by a Tukey test for 5\% significance $(\mathrm{P} \leq 0.05)$. The multifactor regression analysis of STATGRAPHICS PLUS (1995) for Windows Ver. 2.1. was also used.

\section{RESULTS}

The results of this study showed that the productivity of dry aboveground biomass in binary mixtures in 2015 slightly exceeded the corresponding pure cultivated species, and that the differences between them were not significant at 95\% confidence intervals (Table 2).

Productivity was significantly higher in the alfalfa mixture. During the next two years and on average for the period, differences in productivity increased, with mixed crops having statistically significant higher values than monocultures. The average productivity of aboveground biomasses in binary mixtures was $21.5 \%$ higher than in monocultures. It was higher in mixtures of sainfoin and cocksfoot than in pure sainfoin stands from $18.2 \%$ (2015) to $39.4 \%$ (2017). The increase in productivity in these mixtures was the most pronounced, averaging $30.7 \%$, followed by the mixtures of alfalfa and bird's-foot trefoil averages of $18.7 \%$ and $15.0 \%$ respectively.

A similar tendency was observed with regard to dry root biomass productivity (Table 3). In the three years and on average for the period the mixed crops exhibited a significantly higher productivity than the pure ones. The weight of dry root biomass in mixed crops with sainfoin, bird's-foot trefoil and alfalfa increased on average by 39.7, 73.1 and $49.6 \%$, respectively, compared to the pure crops of legumes. 


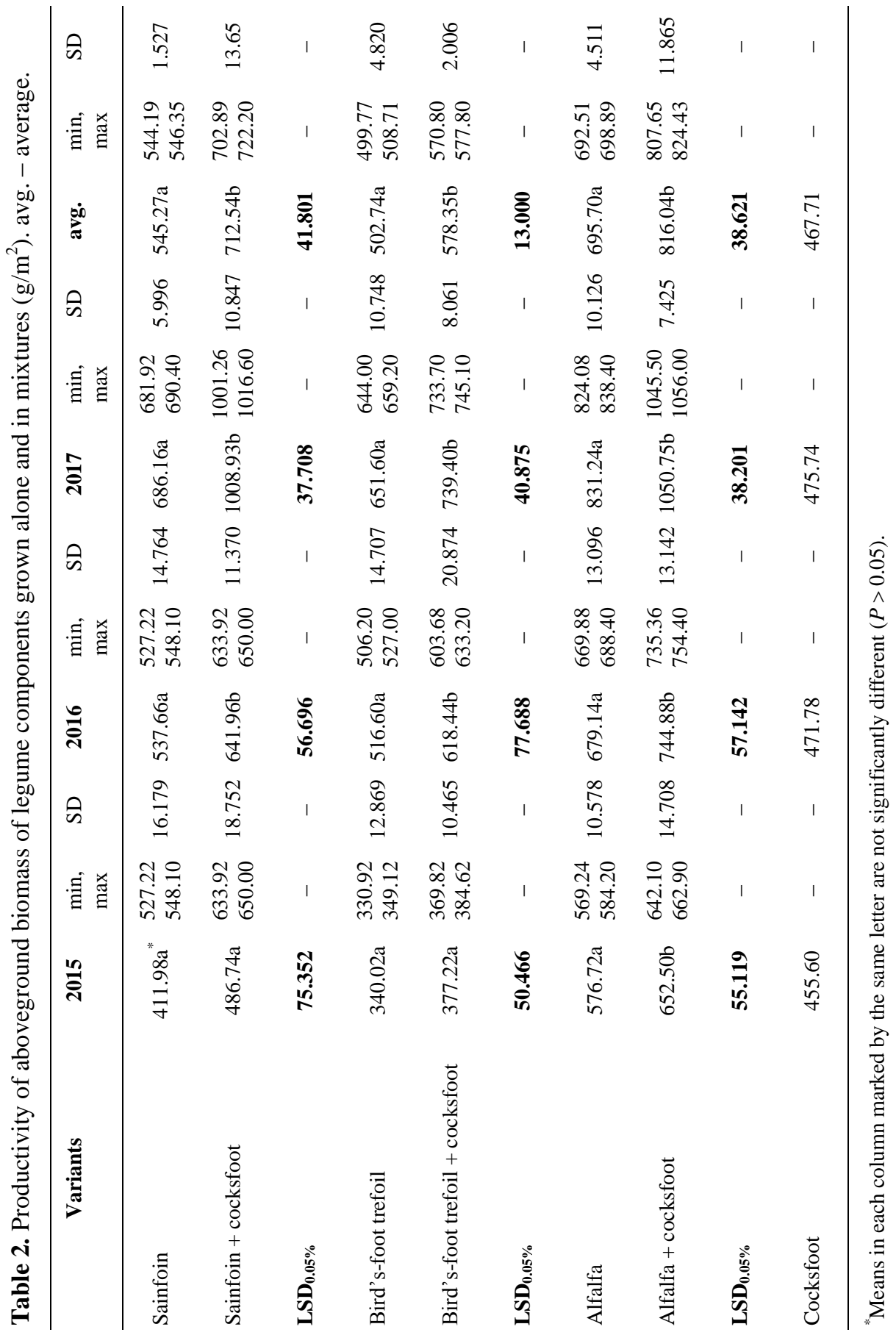




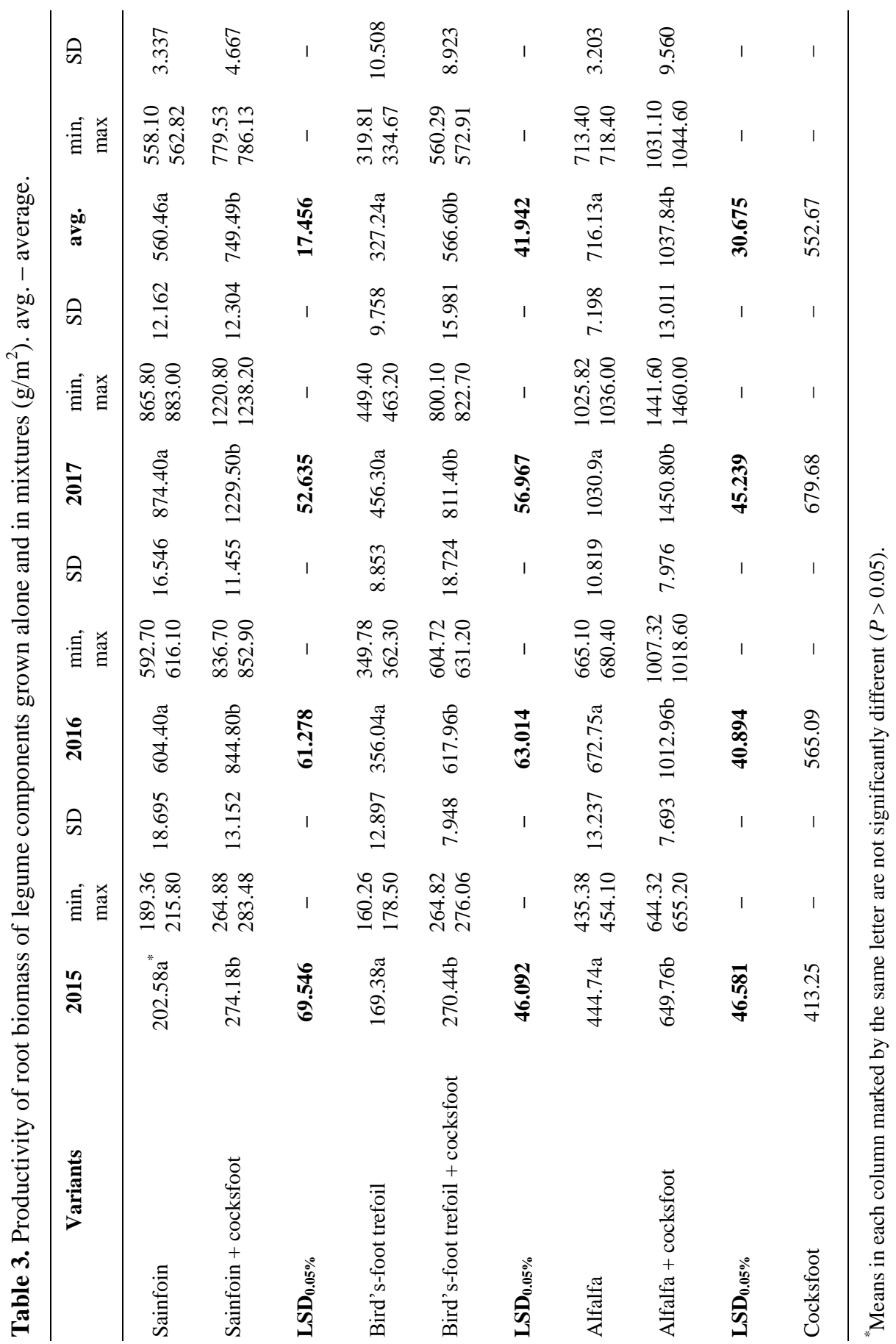


The productivity of dry aboveground biomass in the pure leguminous crops slightly exceeded the corresponding leguminous components in the mixtures. Productivity in mixtures with bird's-foot trefoil was on average $20.6 \%$ higher than the corresponding figures for the legumes in the binary mixtures with cocksfoot; this was followed by sainfoin - on average by $10.7 \%$ and alfalfa - on average by $8.7 \%$. Differences over the years and on average were statistically insignificant (Table 4). In contrast to the leguminous component, the productivity of cereal plants in mixed crops was significantly lower compared to pure cocksfoot on average by $38.5,47.0$ and $51.7 \%$, in mixtures with sainfoin, bird's-foot trefoil and alfalfa respectively.

In relation to the root biomass weight, the productivities of sainfoin, bird's-foot trefoil and alfalfa in the pure and mixed crops in 2015 and 2016 were similar; differences were insignificant (Table 5). In 2017, the weight of pure legumes significantly exceeded the corresponding leguminous plants in mixed crops. The average dry root biomass weight for the study period did not differ statistically between the two stand types, except for the sainfoin variants, where the productivity of the pure crop was $27.1 \%$ higher - a significant figure - than sainfoin plants in the mixture. With regard to the cocksfoot average for 20152017, the productivity of the cereal component in the mixtures of sainfoin and bird's-foot trefoil was significantly the lowest (53.0 and $43.0 \%$ respectively), followed by that of alfalfa (lower by $29.4 \%$ compared to the pure cocksfoot crop).

The productivity factor is genetically determined, and the trend among the studied crops over the years remained unchanged. The weights of both dry aboveground and root biomasses increased with plant growth, but the latter increased very much more than the former. Comparative analysis showed that the aboveground and root biomasses both increase the most intensively in sainfoin from 2015 to 2017 (by 66.5 and 331.6\%), followed by bird's-foot trefoil (by 65.2 and 169.4\%) and alfalfa (by 44.1 and 131.8\%) (Tables 4 and 5).

In mixed crops, the dry aboveground biomass of legume components from 2015 to 2017 increased significantly (differences were non-significant between 2015 and 2016 in alfalfa) (Table 6). A similar increasing trend of the grass component biomasses was found, but differences were not always statistically significant. The most pronounced increase in the productivity of the legume component in the mixture from 2015 to 2017 was found in the bird's-foot trefoil stand (by 1.6 times) whereas that of the grass component was in the sainfoin mixture (by 1.5 times).

The dry root biomass weight, like the dry aboveground biomass weight, increased proportionally in the mixed crops over the years (Table 7). The root productivity of each of the two components increased significantly over the years, and in the legumes, the roots of sainfoin grew the most intensely (almost 4.5 times from 2015 to 2017), and in cocksfoot in mixtures with sainfoin (3 times). 


\begin{tabular}{|c|c|c|c|c|c|c|c|c|c|c|}
\hline 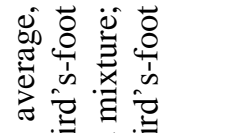 & के & तิ & $\stackrel{9}{9}$ & 1 & సิ & $\frac{\infty}{0}$ & 1 & $\frac{8}{6}$ & $\stackrel{\Re}{\sigma}$ & 1 \\
\hline 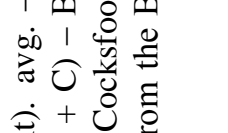 & . & $\underset{\substack{+\infty}}{\substack{\infty \\
\dot{m}}}$ & 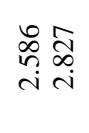 & 1 & 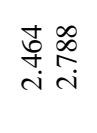 & $\stackrel{n}{2} \underset{i}{i}$ & 1 & 高高 & $\begin{array}{c}\bar{\sigma} \\
\dot{m} \\
\dot{m}\end{array}$ & 1 \\
\hline 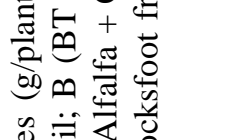 & $\stackrel{\dot{0}}{\vec{\sigma}}$ & 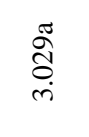 & $\underset{\frac{\pi}{5}}{i}$ & 导 & $\begin{array}{l}\underset{0}{0} \\
\substack{0 \\
i}\end{array}$ & $\begin{array}{l}\stackrel{\infty}{\infty} \\
\stackrel{2}{0} \\
i\end{array}$ & $\stackrel{\mathscr{0}}{\mathscr{0}}$ & $\begin{array}{l}\widetilde{\pi} \\
\infty \\
\infty \\
\dot{r}\end{array}$ & 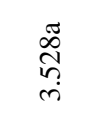 & 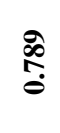 \\
\hline 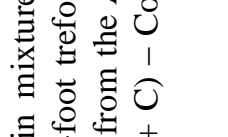 & ڤ & ôे & $\stackrel{\infty}{\infty}$ & 1 & $\stackrel{\bar{m}}{0}$ & $\frac{t}{0}$ & 1 & $\stackrel{8}{0}$ & $\stackrel{\vartheta}{0}$ & 1 \\
\hline 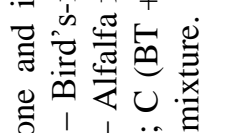 & 香总 & $\begin{array}{l}\bar{n} \\
\\
\end{array}$ & 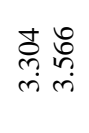 & 1 & \&̊요 & $\begin{array}{l}\infty \\
\infty \\
\infty \\
i \\
i \\
\dot{i}\end{array}$ & 1 & 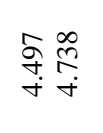 & 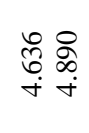 & 1 \\
\hline 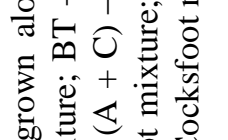 & $\hat{\bar{~}}$ & 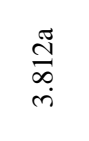 & 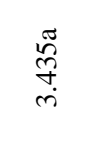 & $\stackrel{\text { ing }}{\text { İ }}$ & $\underset{\stackrel{\sim}{\sim}}{m}$ & 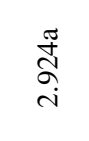 & $\stackrel{R}{\stackrel{R}{9}}$ & $\underset{\substack{\infty \\
\stackrel{\infty}{0} \\
+}}{+}$ & $\begin{array}{l}\stackrel{0}{\tilde{2}} \\
\stackrel{+}{+}\end{array}$ & $\stackrel{n}{\stackrel{n}{S}}$ \\
\hline 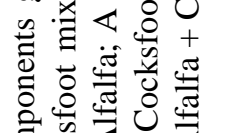 & ڤิ & त̂̀ & $\stackrel{2}{3}$ & 1 & 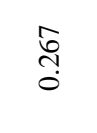 & ֻุర్ & 1 & $\frac{1}{0}$ & तิ & 1 \\
\hline 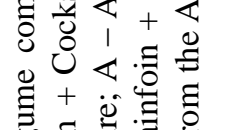 & 百 菎 & 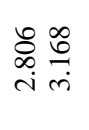 & 突尽 & 1 & $\begin{array}{l}\mathscr{D} \\
\stackrel{0}{0} \text { हे } \\
\text { i }\end{array}$ & 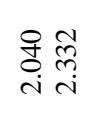 & 1 & $\begin{array}{l}\infty \\
\infty \\
b \infty \\
b i \infty \\
\dot{m i n}\end{array}$ & 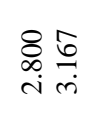 & 1 \\
\hline 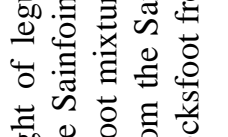 & ัํํ & 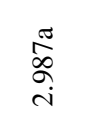 & 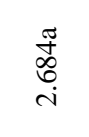 & 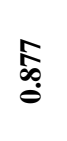 & $\underset{\substack{\mathscr{Q} \\
\infty \\
i}}{i}$ & $\begin{array}{l}\stackrel{\mathscr{D}}{\infty} \\
\stackrel{\sim}{i}\end{array}$ & 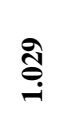 & 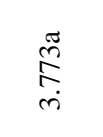 & $\begin{array}{l}\text { 苼 } \\
\text { ì }\end{array}$ & ڤ̊̊ \\
\hline 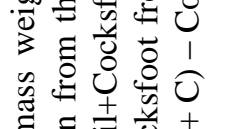 & ڤิ & $\tilde{\wp}$ & $\frac{+}{9}$ & 1 & 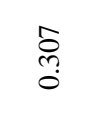 & $\frac{\bar{\sigma}}{0}$ & 1 & $\stackrel{+}{\infty}$ & $\frac{8}{9}$ & 1 \\
\hline 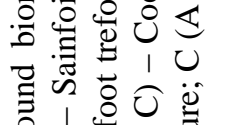 & 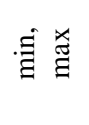 & 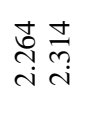 & 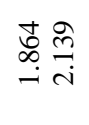 & 1 & 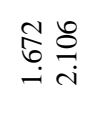 & 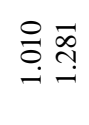 & 1 & 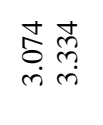 & $\stackrel{\infty}{\stackrel{n}{i}}$ & 1 \\
\hline 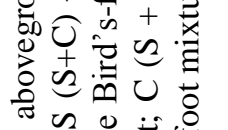 & 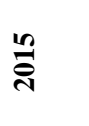 & 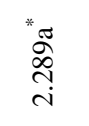 & 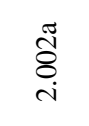 & $\stackrel{\overrightarrow{0}}{\circ}$ & 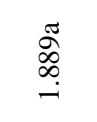 & $\stackrel{\widetilde{\Xi}}{\stackrel{\Xi}{ت}}$ & $\stackrel{\Xi}{=}$ & 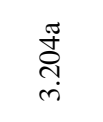 & 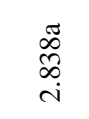 & 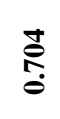 \\
\hline 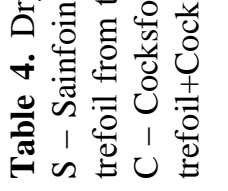 & 苞 & 0 & $\begin{array}{l}0 \\
0 \\
+ \\
n \\
n \\
n\end{array}$ & 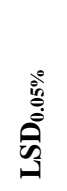 & $\stackrel{\check{n}}{ }$ & 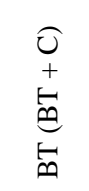 & ڤ్ & $\varangle$ & $\begin{array}{l}0 \\
+ \\
+ \\
\vdots \\
4\end{array}$ & 总 \\
\hline
\end{tabular}




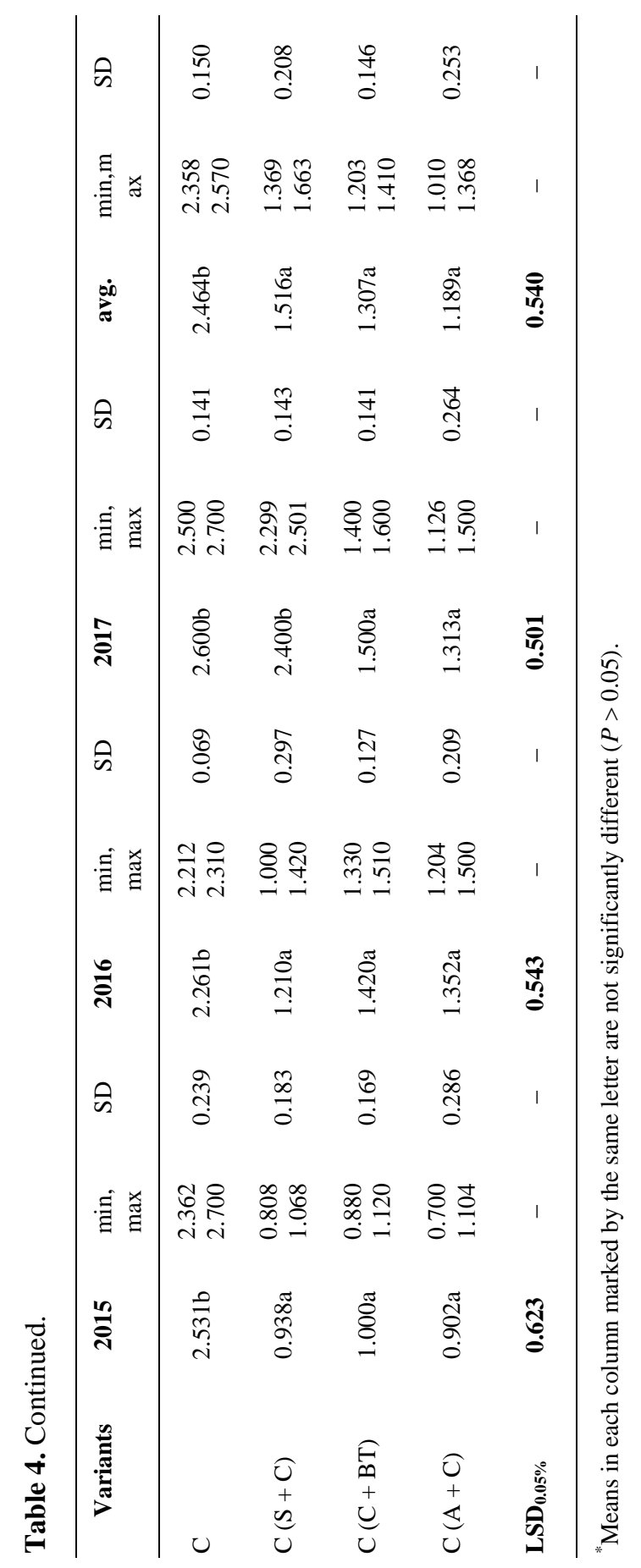




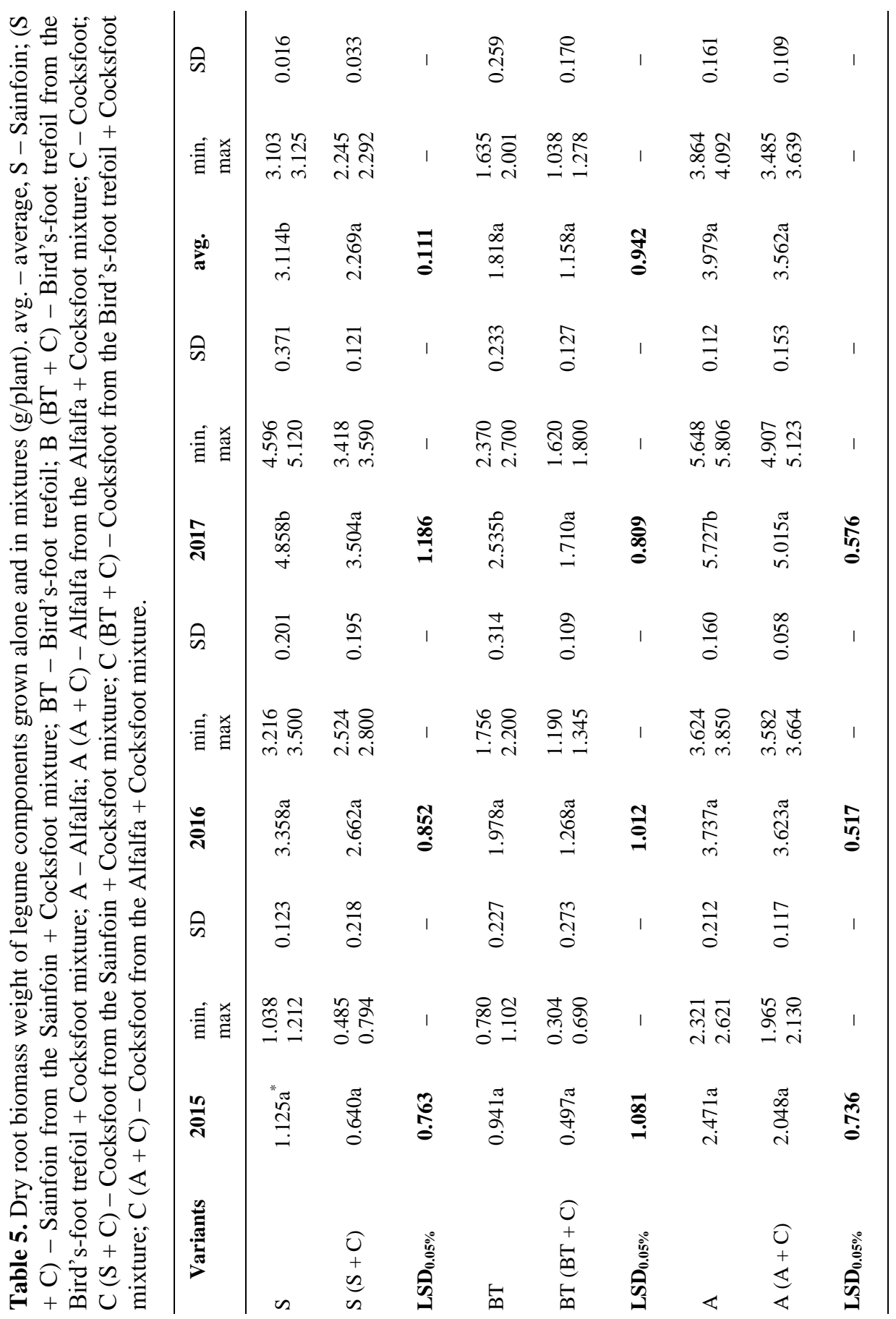




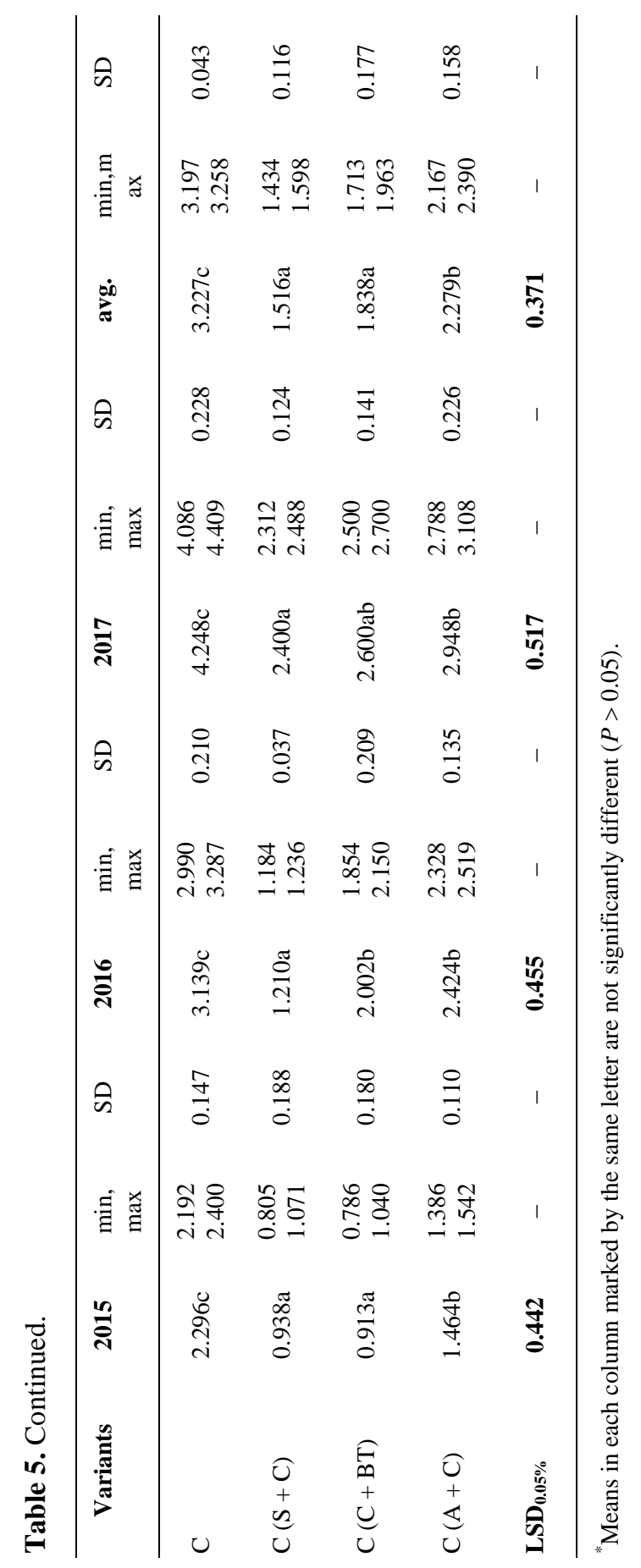


Table 6. Dry aboveground biomass weight of grass and legume components in binary mixtures (g/plant).

\begin{tabular}{lcccccc}
\hline \multicolumn{1}{c}{ Year } & Sainfoin & Cocksfoot & $\begin{array}{c}\text { Bird's-foot } \\
\text { trefoil }\end{array}$ & Cocksfoot & Alfalfa & Cocksfoot \\
\hline 2015 & $2.002 \mathrm{a}^{*}$ & $0.938 \mathrm{a}$ & $1.123 \mathrm{a}$ & $1.000 \mathrm{a}$ & $2.838 \mathrm{a}$ & $0.902 \mathrm{a}$ \\
2016 & $2.684 \mathrm{~b}$ & $1.210 \mathrm{a}$ & $2.186 \mathrm{~b}$ & $1.420 \mathrm{ab}$ & $2.984 \mathrm{a}$ & $1.352 \mathrm{a}$ \\
2017 & $3.435 \mathrm{c}$ & $2.400 \mathrm{~b}$ & $2.924 \mathrm{c}$ & $1.500 \mathrm{~b}$ & $4.763 \mathrm{~b}$ & $1.313 \mathrm{a}$ \\
Average & 2.707 & 1.516 & 2.078 & 1.307 & 3.528 & 1.189 \\
LSD $_{0.05 \%}$ & 0.429 & 0.486 & 0.428 & 0.436 & 0.634 & 0.812 \\
\hline
\end{tabular}

"Means in each column marked by the same letter are not significantly different $(P>0.05)$.

Table 7. Dry root biomass weight of grass and legume components in binary mixtures (g/plant).

\begin{tabular}{lcccccc}
\hline \multicolumn{1}{c}{ Year } & Sainfoin & Cocksfoot & $\begin{array}{c}\text { Bird's-foot } \\
\text { trefoil }\end{array}$ & Cocksfoot & Alfalfa & Cocksfoot \\
\hline 2015 & $0.640 \mathrm{a}^{*}$ & $0.938 \mathrm{a}$ & $0.497 \mathrm{a}$ & $0.913 \mathrm{a}$ & $2.048 \mathrm{a}$ & $1.464 \mathrm{a}$ \\
2016 & $2.662 \mathrm{~b}$ & $1.210 \mathrm{a}$ & $1.268 \mathrm{~b}$ & $2.002 \mathrm{~b}$ & $3.623 \mathrm{~b}$ & $2.424 \mathrm{~b}$ \\
2017 & $3.504 \mathrm{c}$ & $2.400 \mathrm{~b}$ & $1.710 \mathrm{~b}$ & $2.600 \mathrm{c}$ & $5.015 \mathrm{c}$ & $2.948 \mathrm{~b}$ \\
Average & 2.269 & 1.516 & 1.158 & 1.838 & 3.562 & 2.279 \\
LSD $_{0.05 \%}$ & 0.582 & 0.460 & 0.589 & 0.569 & 0.368 & 0.524 \\
\hline
\end{tabular}

"Means in each column marked by the same letter are not significantly different $(P>0.05)$.

Fig. 1 shows that the cultivation system influenced the degree of damage caused by Sitona species. Among the pure crops, bird's-foot trefoil had the highest proportion of damaged nodules and alfalfa the lowest: the difference between the two variants was significant. Nodules damaged by the larvae of Sitona weevils in mixed crops decreased by $33.5 \%$ on average (sainfoin + cocksfoot), by $50.3 \%$ (bird's-foot trefoil + cocksfoot) and by $55.6 \%$ (alfalfa + cocksfoot) compared to pure legumes: the differences were significant at $95 \%$ confidence intervals. Damage reduction was the most pronounced in the alfalfa mixture, where the percentage of damaged nodules was the lowest (20.8\%). Among the mixed crops, the damage rate varied from 20.8 to $40.5 \%$, but there were no significant differences between them.

Reducing weevil damage in mixed crops increases plant productivity. A strong negative correlation was found between the proportion of damaged nodules and the productivity of root and aboveground biomasses $(r=-0.886$ and $r=-0.846$, respectively). 


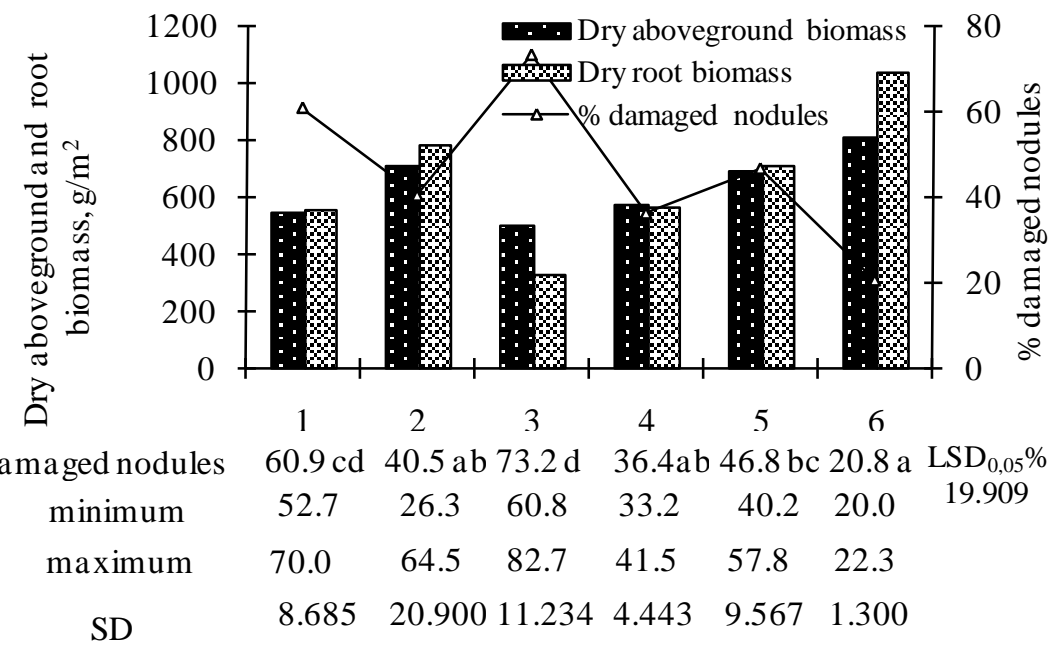

Fig. 1. Influence of damage of Sitona spp. (\% damaged nodules) on productivity in pure and mixed crops averaged for 2015-2017. 1 - Sainfoin; 2 - Sainfoin from the Sainfoin + Cocksfoot mixture; 3 - Bird's-foot trefoil; 4 - Bird's-foot trefoil from the Bird's-foot trefoil + Cocksfoot mixture; 5 - Alfalfa; 6 - Alfalfa from the Alfalfa + Cocksfoot mixture.

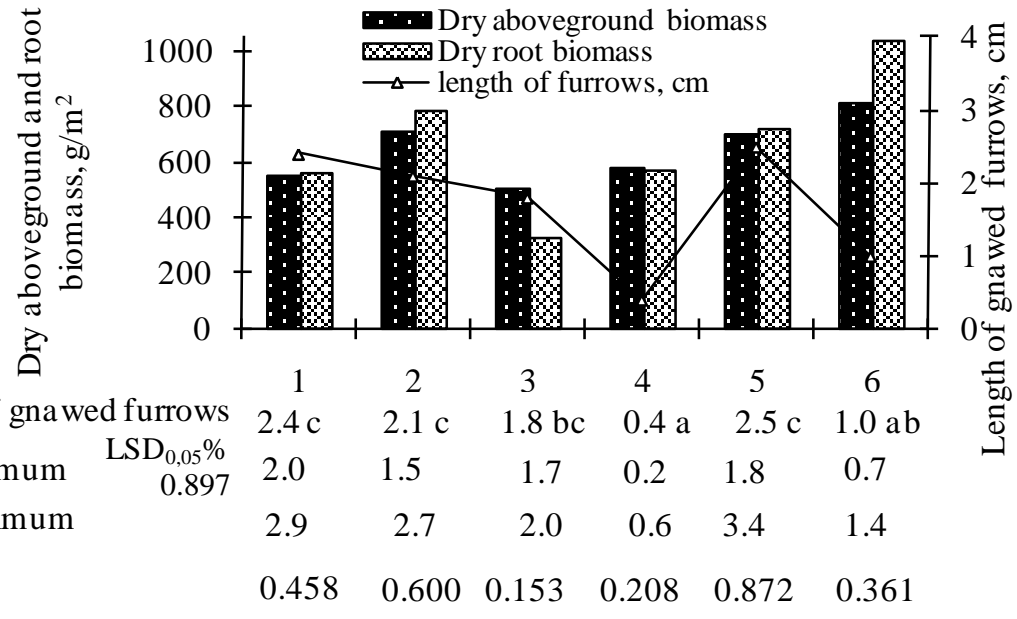

Fig. 2. Influence of damage of Otiorrhynchus ligustici (length of gnawed furrows, $\mathrm{cm}$ ) on productivity in pure and mixed crops averaged for 2015-2017. Abbreviations like in the Fig. 1. 
Damage by $O$. ligustici was reduced to a different extent in the mixed stand as compared to the pure crops (Fig. 2). The damage caused by the alfalfa snout beetle, expressed by the length of the gnawed spiral furrows in mixed crops with sainfoin, bird'sfoot trefoil and alfalfa decreased considerably - by 12.5, 77.8 and 59.5\%, respectively compared to the pure crops. The most pronounced reduction in the furrows took place in the mixture of bird's-foot trefoil with cocksfoot, while in the pure stands, the legume crop had the lowest value of this indicator (on average, a furrow length of $1.8 \mathrm{~cm}$ per root compared to $2.4 \mathrm{~cm}$ in sainfoin and $2.5 \mathrm{~cm}$ in alfalfa). The difference in values between those two crops was statistically significant.

In the mixture of alfalfa and cocksfoot, the degree of damage by $O$. ligustici was significantly lower compared to the pure stands, whereas in the sainfoin variants the difference was insignificant. There were no statistical differences in the furrow lengths between the pure perennial crops, whereas between the mixed crops of bird's-foot trefoil and alfalfa the values were significantly lower than the sainfoin mixture. The correlation coefficient between the root and aboveground biomasses with furrow length was negative $(r=-0.151$ and $r=-0.100$, respectively), but unlike the dependence on the damaged nodules by Sitona weevils, the correlations were weak.

In order to determine the impact of the damage and plant heights on productivity and whether they had any influence, a regression analysis based on the root and aboveground productivity $\left(\mathrm{g} / \mathrm{m}^{2}\right)$ was performed (Tables 8 and 9 ).

The results of the analysis of variance showed that the linear component in the regression of the dry aboveground biomass and dry root biomass with respect to the damaged traits was significant.

Models were obtained ( 1 and 2 ) from the comprehensive study of the traits; they demonstrated the complex character of the change in productivity of the dry aboveground and root biomasses, depending on the variability of the damage traits.

The usual types of regression equations were:

(1) $\mathrm{Y}=791.723-5.492 * \mathrm{X}_{1}-67.082 * \mathrm{X}_{2}+0.255 * \mathrm{X}_{3}$

where $\mathrm{Y}$ - productivity of the dry aboveground biomass; $\mathrm{X}_{1}-\%$ damaged nodules, $\mathrm{cm}$;

$\mathrm{X}_{2}$ - length of the gnawed furrows, $\mathrm{cm} ; \mathrm{X}_{3}-$ height, $\mathrm{cm}$;

(2) $\mathrm{Y}=957.208-11.105 * \mathrm{X}_{1}-123.425 * \mathrm{X}_{2}+0.0562 * \mathrm{X}_{3}$

where $\mathrm{Y}$ - productivity of the dry root biomass; $\mathrm{X}_{1}-\%$ damaged nodules, $\mathrm{cm} ; \mathrm{X}_{2}-$

length of the gnawed furrows, $\mathrm{cm} ; \mathrm{X}_{3}-$ height, $\mathrm{cm}$.

Regression analysis (Table 8 ) showed that the damage from $O$. ligustici as expressed by the length of the gnawed furrows had the most negative effect on the productivity of aboveground biomass and that the regression coefficient of -67.082 was statistically significant $(\mathrm{P}=0.0135$ and $\mathrm{P}$ is no greater than 0.05 ; this term is statistically significant at the 95\% confidence level). The regression between the damaged nodules percent and 
productivity of aboveground biomass was weaker $(\mathrm{r}=-5.492)$, but with significant difference $(\mathrm{P}=0.0001)$.

Table 8. Analysis of variance and regression coefficients of the productivity of aboveground biomass of pure and mixed leguminous crops with regard to damage indicators and plant height. Cf - coefficients, SE - standard error, L 95\% - lower 95\%, U $95 \%$ - upper $95 \%$.

Analysis of Variance

\begin{tabular}{lccccc}
\hline \multicolumn{1}{c}{ Source } & Sum of Squares & Cf & Mean Square & F-Ratio & P-Value \\
\hline Model & 166201.0 & 3 & 55400.4 & 16.50 & $0.0001^{*}$ \\
Residual & 47018.9 & 14 & 3358.49 & - & - \\
Total (Corr.) & 213220.0 & 17 & - & - & - \\
\hline
\end{tabular}

*If the P-value in the ANOVA table is less than 0.05 , there is a statistically significant relationship between the variables at the $95 \%$ confidence level.

\begin{tabular}{|c|c|c|c|c|c|c|}
\hline \multicolumn{7}{|c|}{ Regression coefficients } \\
\hline Trait & Cf & SE & t Stat & P-value & L $95 \%$ & U $95 \%$ \\
\hline Constant & 791.723 & 90.7671 & 8.72257 & 0.0000 & 597.046 & 986.399 \\
\hline$\%$ damaged nodules & $-5.4921 *$ & 0.9775 & -5.61874 & 0.0001 & -7.5885 & -3.3956 \\
\hline $\begin{array}{l}\text { Length of the gnawed } \\
\text { furrows, } \mathrm{cm}\end{array}$ & $-67.0817 *$ & 23.7529 & -2.82415 & 0.0135 & -16.1367 & -118.027 \\
\hline Height, $\mathrm{cm}$ & 0.2548 & 1.1438 & 0.2228 & 0.8269 & 2.7081 & 2.1985 \\
\hline
\end{tabular}

${ }^{*}$ There is a significant difference $(\mathrm{P}<0.05)$ between the trait and the dry aboveground biomass.

The impact of the damage traits on the productivity of the root biomass was more pronounced (Table 9). The length of spiral furrows has the highest significant negative effect on the root weight (regression coefficient $=-123.425$ at $\mathrm{P}=0.0120$ ), followed by the degree of damaged nodules with a significant negative influence (regression coefficient $=$ - 11.105). The height of the plants had no effect on root biomass productivity.

\section{DISCUSSION}

The productivity and quality of high-protein forage crops increasingly needed for livestock development in Bulgaria is an important and permanent task in agriculture. It is usually accomplished through the use of high-yielding forage species, which at the same time can provide balanced agricultural production and the production of competitive agricultural and animal products. 
Table 9. Analysis of variance and regression coefficients of the productivity of root biomass of pure and mixed leguminous crops with regard to damage indicators and plant height. Cf - coefficients, SE - standard error, L 95\% - lower 95\%, U 95\% - upper 95\%.

\begin{tabular}{|c|c|c|c|c|c|c|c|}
\hline \multicolumn{8}{|c|}{ Analysis of Variance } \\
\hline Source & \multicolumn{2}{|c|}{ Sum of Squares } & $\mathbf{C f}$ & \multicolumn{2}{|l|}{ Mean Square } & F-Ratio & P-Value \\
\hline Model & \multicolumn{2}{|c|}{718303.0} & 3 & 239434.0 & \multicolumn{2}{|c|}{21.96} & $0.0001^{*}$ \\
\hline Residual & \multicolumn{2}{|c|}{152622.0} & 14 & 10901.6 & \multicolumn{2}{|c|}{-} & - \\
\hline Total (Corr.) & \multicolumn{2}{|c|}{870925.0} & 17 & - & \multicolumn{2}{|c|}{-} & - \\
\hline \multicolumn{8}{|c|}{$\begin{array}{l}\text { *If the P-value in the ANOVA table is less than } 0.05 \text {, there is a statistically significant relationship } \\
\text { between the variables at the } 95 \% \text { confidence level. }\end{array}$} \\
\hline \multicolumn{8}{|c|}{ Regression coefficients } \\
\hline Trai & & Cf & SE & t Stat & P-value & L 95\% & U 95\% \\
\hline Constant & & 957.208 & 163.531 & 5.8534 & 0.0001 & 606.468 & 1307.95 \\
\hline$\%$ damaged $\mathrm{n}$ & lules & $-11.105^{*}$ & 1.7611 & -6.3059 & 0.0020 & -14.8821 & -7.3279 \\
\hline $\begin{array}{l}\text { Length of the } \\
\text { furrows, } \mathrm{cm}\end{array}$ & awed & $-123.425^{*}$ & 42.7947 & -2.8841 & 0.0120 & -31.6393 & -215.211 \\
\hline Height, $\mathrm{cm}$ & & 0.0562 & 2.0608 & 0.0273 & 0.9786 & 4.4762 & 4.3637 \\
\hline
\end{tabular}

${ }^{*}$ There is a significant difference $(\mathrm{P}<0.05)$ between the trait and the dry aboveground biomass.

The productivity of legume components (alfalfa, sainfoin and bird's-foot trefoil) and cocksfoot in the mixtures were lower than that of pure legumes and grass during the years of this study. An analogous tendency was reported by BERDAHL et al. (2001) with regard to a higher dry matter yield of a grass species in a pure stand as compared to a mixture of alfalfa and grass.

Productivity is an indicator influenced not only by the system of cultivation but also by many other factors, the key to which is the presence of economically important pests. Among them, high numbers of polyphagous root pests Otiorrhynchus ligustici and Sitona weevils can reduce or even completely destroy the harvest (SHIELDS et al. 2008). As the use of plant protection products for managing pests is difficult because many of them lead a hidden lifestyle, the application of alternatives to conventional methods is of great importance: one of these approaches is to diversify the plants in cultivation systems

In our study, the damage caused by Sitona spp. and Otiorrhynchus ligustici in mixed crops was reduced to varying extents in relation to the monocultures. The reduction in damage by nodule weevils was the most pronounced in the alfalfa mixture. Similar results for significantly lower numbers of Sitona weevils and less damage caused by them in a mixture of peas with white mustard versus pure crops were reported by WNUK \& WIECH (1996).

It was found that the nodules preferred and damaged by the Sitona weevil larvae in pure crops were those of sainfoin, followed by alfalfa and bird's-foot trefoil. Similar results were 
reported by BARRATT \& BYERS (1991), according to which alfalfa was significantly more preferred and susceptible to damage by Sitona hispidulus (FABRICIUS, 1776) than bird'sfoot trefoil. Possible reasons for the preference of Sitona weevils for some species may be the existence of a signalling mechanism enabling the larvae to find the roots and the nodules formed on them, as well as a higher nodule density (ZHANG et al. 2006). The feeding of Sitona larvae had a negative effect on alfalfa growth, reducing this to $40 \%$ per year according to ARBAB et al. (2008). The inclusion of Medicago sativa in a mixture with other crops (for example, with sainfoin) decreased weevil densities and led to higher forage yields (DiZAJA et al. 2015).

ROSHANDEL \& NOORBAKHSHIAN (2009) found that average numbers of Hypera postica (GYLLENGAL, 1813) larvae, pest population size and percentage of infestation were all significantly lower in mixed treatments in comparison with pure alfalfa and red clover. In addition, according to those authors, the forage yield was higher in mixed treatments than in pure legume crops.

There is significant evidence showing that the increase in species diversity in the crop systems considerably improves the management and control of harmful insects, which in itself is an economically and ecologically sustainable method of control (LUNDGREN et al. 2008, GLINWOOD et al. 2009). One of the reasons for this is the reduced ability of pests to find their preferred host plants, i.e. associative resistance (AGRAWAL et al. 2006, RANDLKOFER et al. 2010).

\section{CONCLUSIONS}

- The productivities of aboveground and root biomasses in binary mixtures were significantly higher compared to corresponding legume monocultures on average by 30.7 and $39.7 \%$ respectively in the mixture with sainfoin, by 15.0 and $73.1 \%$ in the mixture with bird's-foot trefoil and by 18.7 and $49.6 \%$ in the mixture with alfalfa.

- The weight of dry aboveground biomass in the pure leguminous crops slightly exceeded the corresponding leguminous components in the mixtures, whereas the productivity of cereal plants in mixed crops was significantly lower compared to pure cocksfoot on average by $38.5,47.0$ and $51.7 \%$ in mixtures with sainfoin, bird's-foot trefoil and alfalfa respectively. A similar tendency was observed with regard to dry root biomass.

- Damage to nodules by Sitona larvae in mixtures decreased significantly, on average by $33.5 \%$ (sainfoin + cocksfoot), by $50.3 \%$ (bird's-foot trefoil + cocksfoot) and by $55.6 \%$ (alfalfa + cocksfoot) compared to pure grown legumes. A strong negative correlation was found between the proportion of damaged nodules and the productivity of root and aboveground biomass $(r=-0.886$ and $r=-0.846$, respectively). 
- The damage caused by Otiorrhynchus ligustici expressed by the length of gnawed furrows in the mixtures with sainfoin, bird's-foot trefoil and alfalfa decreased considerably by $12.5,77.8$ and $59.5 \%$, respectively, compared to the pure crops. Significant furrow reduction was found in the mixture of bird's-foot trefoil and alfalfa with cocksfoot compared to pure crops. The damage caused by the alfalfa snout beetle had the most significant negative effect on aboveground and root biomass productivity.

\section{REFERENCES}

Agrawal A.A., Lau J.A., Hamback P.A. 2006. Community heterogeneity and the evolution of interactions between plants and insect herbivores. The Quarterly Review of Biology, 81 (4): 349-376.

Albayrak S., Turk M., Yuksel O., Yilmaz M. 2011. Forage yield and the quality of perennial legume-grass mixtures under rainfed conditions. Notulae Botanicae Horti Agrobotanici ClujNapoca, 39 (1): 114-118.

ANDow D. 1991. Vegetational diversity and arthropod population response. The Annual Review of Entomology, 36: 561-586.

Arbab A., Kontodimas D.C., McNeill M.R. 2008. Modeling Embryo Development of Sitona discoideus GyllenHAL (Coleoptera: Curculionidae) Under Constant Temperature. Environmental Entomology, 37 (6): 1381-1388.

BARRATT B.I.P., BYERS R.A. 1991. Legume seedling feeding preferences of adult Sitona hispidulus (F.) (Coleoptera: Curculionidae). Environmental Entomology, 21 (1): 103-106.

Berdahl J.D., KARn J.F., HendRICKSON J.R. 2001. Dry Matter Yields of Cool-Season Grass Monocultures and Grass-Alfalfa Binary Mixtures. Agronomy Journal, 93 (2): $463-467$.

CASH D. 2007. Factors Affecting Alfalfa Stand Longevity in Montana. SW03-063 (project overview), State: Montana. Internet: https://projects.sare.org/project-reports/sw03-063/

CinAR S., Hatipoglu R. 2014. Forage yield and botanical composition of mixtures of some perennial warm season grasses with alfalfa (Medicago sativa L.) under Mediterranean conditions. Turkish Journal of Field Crops, 19 (1): 13-18.

Cinar S., Hatipoglu R., Gundel F.D., Aktas A., Avci M. 2014. Performances of some perennial warm season grasses alfalfa (Medicago sativa L.) mixtures under Mediterranean conditions. Turkish Journal of Field Crops, 19 (2): 212-218.

Dizaja H.M., Mazaheria D., Mohammadzadehb A., NAminc P.H. 2015. Forage production and population of alfalfa weevil (Hypera postica) in intercropping of alfalfa and sainfoin. Journal of Crop Improvement, 29 (4): 455-464.

FARgione J., Brown C.S., Tilman D. 2003. Community assembly and invasion: An experimental test of neutral versus niche processes. Proceedings of the National Academy of Sciences of the United States ofAmerica, 100 (15): 8916-8920.

Feng M., Wang J., Zhang T., JiAng R., CHENG X. 2011. Effect of planting alfalfa in tea plantation on arthropod community structure. Journal of Qingdao Agricultural University (Natural Science) 


\section{1-04}

GERRISH, J. 2001. Species stability in diverse pasture mixtures. [in:] T. TerRILL, K. CASSIDA, D. Belesky, J. Berdahl, M. Phillips, M. Williams, M. Wiedenhoeft (eds). American Forage and Grassland Council Proceedings, Vol. 10. Proceedings of the 2001 Forage and Grassland Conference, Holiday Inn Northwest Arkansas Convention Center, Springsdale, Arkansas, April 22-25, 2001. American Forage and Grassland Council, Georgetown, 212-216.

Glinwood R., Ahmed E., Qvarfordt E., Ninkovic V., Pettersson J. 2009. Airborne interactions between undamaged plants of different cultivars affect insect herbivores and natural enemies. Arthropod-Plant Interactions, 3 (4): 215-224.

Hurej M., Twardowski, J. 2003. The influence of mixed cropping of yellow lupin and spring triticale on phytophagous and beneficial insects. Zeszyty Problemowe Postępów Nauk Rolniczych, 495: 243-250. (in Polish)

Lundgren J.G., Hesler L.S., Tilmon K., Dashiell K., Scott R. 2008. Direct effects of soybean varietal selection and Aphis glycines-resistant soybeans on natural enemies. Arthropod-Plant Interactions, 3 (1): 9-16.

Minns A., Finn J., Hector A., Caldeira M., Joshi J., Palmborg C., Schmid B., Scherer-Lorenzen M., SPEHN E., Troubis A. 2001. The Functioning of European Grassland Ecosystems: Potential Benefits of Biodiversity to Agriculture. Outlook on Agriculture, 30 (3): 179-185.

MoONEn A.-C., BÀRBERI P. 2008. Functional biodiversity: An ecosystem approach. Agriculture, Ecosystems and Environment, 127 (1-2): 7-21.

Picasso V.D., Brummer E.C., Liebman M., Dixon P. M., Wilsey B.J. 2011. Diverse perennial crop mixtures sustain higher productivity over time based on ecological complementarity. Renewable Agriculture and Food Systems, 26 (4): 317-327.

Randlkofer B., Obermaier E., Hilker M., Meiners T. 2010. Vegetation complexity - The influence of plant species diversity and plant structures on plant chemical complexity and arthropods. Basic and Applied Ecology, 11 (5): 383-395.

RISCH S.J. 2005. Intercropping as cultural pest control: prospects and limitations. Environmental Management, 7 (1): 9-14.

Roshandel S., Noorbakhshian J. 2009. Effect of mixed cropping of alfalfa and red clover on population density and infestation rate of alfalfa weevil Hypera postica (Col.: Curculionidae). Iranian Society of Entomological Journal, 36 (1): 29-38.

SANDERSON M.A. 2010. Stability of production and plant species diversity in managed grasslands: A retrospective study. Basic and Applied Ecology, 11 (3): 216-224.

Sastawa B.M., LAwan M., Maina Y.T. 2004. Management of insect pests of soybean: effects of sowing date and intercropping on damage and grain yield in the Nigerian Sudan savanna. Crop Protection, 23 (2): 155-161.

SHANIN J. 1977. Methodology of field experience. Bulgarian Academy of Sciences Publishing House, Sofia.

Shields E.J., Neumann G., Testa A. 2008. Alfalfa Snout Beetle, Otiorhynchus ligustici L. (Coleoptera: Curculionidae): Methods for egg collection and larval rearing. Great Lakes Entomologist, 40 (1-2): 62-67. 
Skinner R.H., SAnderson M.A., Tracy B.F., Dell C.J. 2006. Above- and belowground productivity and soil carbon dynamics of pasture mixtures. Agronomy Journal, 98 (2): 320-326.

Sleugh B., Moore K.J., George J.R., Brummer E.C. 2000. Binary legume-grass mixtures improve forage yield, quality, and seasonal distribution. Agronomy Journal, 92 (1): 24-29.

Smith H.A., MCSorley R. 2000. Intercropping and pest management: a review of major concepts. The American Entomologists, 46 (3): 154-161.

StRaub C.S., Simasek N.P., GAPINSKi M.R., DOHM R., AiKens E.O., Muscella S. 2013. Influence of nonhost plant diversity and natural enemies on the potato leafhopper, Empoasca fabae, and pea aphid, Acyrthosiphon pisum, in alfalfa. Journal of Pest Science, 86 (2): 235-244.

Tharmaraj J., Chapman D.F., Nie Z.N., Lane A.P. 2007. Herbage accumulation, botanical composition, and nutritive value of five pasture types for dairy production in southern Australia. Austral Journal of Agricultural Research, 59 (2): 127-138.

Tillman G., Schomberg H., Phatak S., Mullinix B., Lachnicht S., Timper P., Olson D. 2004. Influence of cover crops on insect pests and predators in conservation tillage cotton. Journal of Economic Entomology, 97 (4): 1217-1232.

TiLmAn D. 1999. The ecological consequences of changes in biodiversity: A search for general principles. Ecology, 80 (5): 1455-1474.

TOOKER J.F., Frank S.D. 2012. Genotypically diverse cultivar mixtures for insect pest management and increased crop yields. Journal of Applied Ecology, 49 (5): 974-985.

TRACY B.F., SANDERSON M.F. 2004. Forage productivity, species evenness and weed invasion in pasture communities. Agriculture, Ecosystems and Environment, 102 (2): 175-183.

Velasquez de Castro A.J., Alonso Zarazaga M.A., Outerelo R. 2007. Systematics of Sitonini (Coleoptera: Curculionidae: Entiminae), with a hypothesis on the evolution of feeding habits. Systematic Entomology, 32 (2): 312-331.

WNUK A., WIECH K. 1996. The effect of spacing, date of sowing and intercropping on the occurrence of pea pests. Roczniki Nauk Rolniczych seria E, 25 (1-2): 9-14.

Woodward S.L., Waugh C.D., Roach C.G., Fynn D., Phillips J. 2013. Are diverse species mixtures better pastures for dairy farming? Proceedings of the New Zealand Grassland Association, 75 79-84.

Zavaleta E.S., Hulvey K.B. 2004. Realistic species losses disproportionately reduce grassland resistance to biological invaders. Science, 306 (5669): 1175-1177.

Zhang X., Johnson S.N., Gregory P.J., Crawford J.W., Young I.M., Murray P.J., Jarvis S.C. 2006. Modelling the movement and survival of the root-feeding clover weevil, Sitona lepidus, in the root-zone of white clover. Ecological Modelling, 190 (1-2): 133-146.

Received: 14 June 2018

Accepted: 17 July 2018 